\title{
On all-around improvement of management quality of practical teaching through undergraduate teaching evaluation
}

\author{
Ying ZHANG \\ Department of Teaching Affairs, Jilin Agricultural University,Changchun, 130118,China \\ email: jlauzy@126.com
}

Keywords: Evaluation of undergraduate teaching; Management of practical teaching; Quality

\begin{abstract}
Management of practical teaching is of vital importance to bring up talents with all-around knowledge, abilities and qualities in the 21st century. This paper is a preliminary study on problems existing in evaluation of practical teaching management and countermeasures for these problems.
\end{abstract}

\section{Introduction}

In 2016, the Undergraduate Teaching Evaluation Expert Group of the Ministry of Education of the PRC evaluated undergraduate teaching in the author's university. Practical teaching is an essential index of subject construction and teaching reform indexes in the undergraduate teaching evaluation system. It is an important part of talent development in institutions of higher learning, a key teaching link to cultivate students' innovational spirit, practical abilities and entrepreneurship, and a critical approach to promoting coordinated development of students' knowledge, abilities and qualities. Therefore, deepening of teaching reform, innovating content and forms of practical teaching and improving quality of practical teaching are to implement the evaluation principle of "promoting reform and construction through evaluation, combining evaluation and construction and focusing on construction." They are also internal needs of enhancing undergraduate teaching. Therefore, management of practical teaching undoubtedly becomes an important part of teaching management in institutions of higher learning. Good management of practical teaching means institutions of higher learning have grasped the key link of their whole teaching management, and is important to improve teaching quality and develop "senior talents with both innovational spirit and practical abilities.”

\section{Imperativeness of improving management level of practical teaching}

In recent years, though institutions of higher learning have made some achievements in their teaching management, they are faced with a series of problems against the backdrop of fast-developing higher education, swift expansion of school scale and overall improvement of schooling level. Old-fashioned management concepts of practical teaching, lack of standard process management, incomplete mechanisms and institutions, unclear division of responsibilities and duties and unscientific evaluation-all these problems have directly influenced quality of practical teaching and talent development. To conduct efficient and scientific management of practical teaching is not only an imperative requirement of development situations of higher education but also a necessary path to improve qualities of talents. Currently, to improve management level of practical management has become a must ${ }^{[1]}$.

\section{Major problems existing in management of practical teaching}

Lack of in-depth research and systematic planning.In recent years, institutions of higher learning have increased their hardware input for practical teaching so that their teaching conditions and situations have taken on a new look. However, under new educational situations, they still lack a comprehensive, systematic and in-depth research and thinking of various teaching tasks. As a result, 
their practical teaching is crying for an all-around and sustainable construction thinking and development plan ${ }^{[2]}$.

Inadequate emphasis on and intensity of reform. In terms of management, reform of practical teaching lacks systematic and long-term planning. Reform depth and intensity of experiments and internship practices are inadequate in terms of teaching content and system. The teaching content and system of many practical courses still follow traditional modes. Due to old-fashioned teaching modes and teaching methods, the outcomes of teaching plans deviate from the social requirements of practical abilities greatly.

Weak quality management of practical teaching.During the supervision process of teaching quality, evaluation of teaching effects of practical courses often follows same evaluation criterion adopted by theoretical courses. Though the evaluation work becomes much easier in this way, practical teaching differs from theoretical teaching in many ways, and quality supervision of internship is hard ${ }^{[3]}$.

Necessity for improving overall qualities of the faculty and management team.Experiment technicians and teaching management personnel lack necessary service training and incentives. They are even treated unfairly. Consequently, many experiment technicians and management personnel lack confidence and sense of responsibility. Their overall qualities are low and unstable.

Backward management concepts and lack of management innovation.Some management personnel fail to update their management knowledge and concepts immediately. In terms of teaching management and topic application, encouragement policies and positive guidance for the practice link and management personnel are lacking.

\section{Update of practical teaching concepts and improvement of the analytical analysis of management system improvement}

Good teaching management can safeguard teaching quality. However, the prerequisite for improved management level of practical teaching is to update concepts of teaching management. Based on scientific and correct management concepts and ideas, the management system can be further improved and the teaching reform can be deepened.

Promote management through evaluation and efficiently improve management level of practical teaching

In order to further improve undergraduate teaching quality, the Ministry of Education has conducted teaching evaluation of general institutions of higher learning since 2003. According to general evaluation requirements, practical teaching is directly related to realization of talent training purposes and schooling quality. The level-1 index of the undergraduate teaching evaluation, namely "specialty construction and teaching reform," consists of three secondary indexes, namely specialty, course and practical teaching. There are at least six level-2 indexes putting forward requirements in terms of teaching conditions, teaching content and system, quality supervision and teaching effects. It reflects that practical teaching has been relatively independent and complete in undergraduate teaching. It is necessary to emphasize on all-around construction of the link. The promotion of all the above tasks has a close bearing on management of practical teaching ${ }^{[4]}$.

"Teaching management" is a level-1 index among the evaluation index system. It consists of two level-2 indexes, namely management team and quality control. They reflect the important role of management in teaching. Therefore, importance of management of practical teaching is self-evident. During teaching evaluation, it is necessary to adhere to the guideline of "promoting management through evaluation." Through intensified evaluation, teaching management can be comprehensively improved.

Update concepts and implement all-around quality management

Update of practical teaching management concepts and implement all-around quality management to improve teaching quality. All-around quality management of practical teaching includes experiment, internship, course design, social practical and graduation paper (design). The teaching quality supervision system of every link consists of multiple sub-systems, including the objective supervision system, the teaching process supervision system and the teaching information 
supervision system. The all-around quality management supervision system should be student-oriented and aim at improvement of teaching quality. Priority should be given to demands of talent development and teaching. Quality standards of various links should be improved, and feasible supervision methods can be explored. Besides, the strict quality management system can help create a relaxing and flexible teaching environment to encourage personality and characteristic development. To formulate, amend and improve management regulations and systems is basic to enhancement of the practical teaching management. It can promote systemization and standardization of practical teaching. In this way, various teaching links can find rules to follow and quality supervision of teaching process can be materialized.

Plan as a whole and gradually deepen practical teaching reform

During the reform process of practical teaching, lack of forward-looking planning and scientific reform ideas is a common phenomenon. It can lead to inefficient reform results and has become an deficit of teaching management. To deepen teaching reform, it is necessary to conduct an in-depth research of teaching and educational rules of practical teaching; formulate development goals; conduct scientific planning; and gradually promote progress of reform. Plan formulation is equal to clarity of work flow, determination of reform or development goals and construction steps. It is necessary to study educational and teaching rules of practical teaching and explore feasible, scientific and efficient methods and approaches. On the one hand, stick to overall orientation and development goals of school, and keep consistent with overall construction and planning of school; on the other hand, build a perspective of long-term and sustainable development; emphasize on developing and utilizing advantages of unique resources and learn successful experiences from counterparts $^{[5]}$.

Rationalize the teaching management system and enhance the cross-department and personnel cooperation

Clear labor distribution and cooperation between departments can guarantee smooth operation and coordinated development of teaching management. Therefore, based on characteristics of practical teaching, it is necessary to rationalize the teaching management system and enhance the cross-department and personnel cooperation and communication so as to avoid acting of their own free will or mutual restriction. Besides, as to the two-level management model of university and college, a college is a relatively independent teaching management unit and a principal part of the teaching management system. It is necessary to fully stimulate initiative and creativity of the grassroots teaching units so that they can make full use of their practical teaching experiences and participate in teaching management and decision-making process. Besides, teaching management modes with characteristics should be built up so that the whole practical teaching management system can keep running in an orderly state.

\section{Conclusion}

In order to achieve more scientific and standard planning, guidance, coordination and control, institutions of higher learning should conduct an in-depth analysis of problems existing in management of practical teaching, and explore management mechanisms and modes for practical teaching based on innovational ideas, thinking and measures. Besides, various vigorous measures will be adopted so as to guarantee content, time and quality of practical teaching and realize talent development goals of institutions of higher learning.

\section{References}

[1] Zhang Ke. To strengthen the construction of campus practice base, to cultivate practical talents[J]. Research and Exploration in Laboratory,2009,28 (2).

[2] Deng Guangtao.Reforming practical teaching management to cultivate students'innovative ability[J]. Research and Exploration in Laboratory, 2013(6):349-352.

[3] Zhao Jianhong. Construction of practical teaching system in the training mode of Applied 
Talents[J].Heilongjiang Researches on Higher Education,2011(5):184-186.

[4] Lin Haidan. Laboratory team construction mechanisms in colleges and universities[J]. Research and Exploration in Laboratory,2012(2):173-174.

[5] Zhang Yajun. Research and practice on quality evaluation of experimental teaching in common colleges and universities[J]. Experimental Technology and Management,2011(3):259-262. 